\title{
Serum Heat Shock Protein 70, S100A12 and Matrix Gla Protein in Childhood Obesity and Metabolic
} Syndrome

\section{Çocukluk Çağı Obezite ve Metabolik Sendromda Serum Heat Şok Protein 70, S100A12 ve Matriks Gla Protein}

\author{
Ummugulsum Can ${ }^{1,{ }^{*},}$ Muammer Buyukinan ${ }^{2}$, Asuman Guzelant ${ }^{3}$, Adnan Karaibrahimoğlu $^{4}$ \\ ${ }^{1}$ Konya Education and Research Hospital, Department of Biochemistry, Konya, Turkey \\ ${ }^{2}$ Konya Education and Research Hospital, Department of Pediatric Endocrinology, Konya, Turkey \\ ${ }^{3}$ Konya Education and Research Hospital, Department of Microbiology Konya, Turkey \\ ${ }^{4}$ Necmettin Erbakan University Meram Medical School, Medical Education and Informatics Department Biostatistics \\ Expert Konya, Turkey
}

\begin{abstract}
Objectives: The primary cause of the metabolic syndrome appears to be obesity that is associated with a low-grade inflammatory state resulting from insulin resistance in both adult and pediatric populations. Heat shock protein 70, S100A12 and matrix Gla protein are involved in chronic inflammatory diseases. We aimed to evaluate the association between these markers and childhood obesity and metabolic syndrome.
\end{abstract}

Materials and Methods: This study was performed with 45 obese children aged $10-15$ years and 47 children with metabolic syndrome aged 10-15 years. Serum heat shock protein 70 , S100A12 and matrix Gla protein levels were measured by using ELISA method.

Results: Serum matrix Gla protein and S100A12 levels in obese subjects were significantly higher than metabolic syndrome groups $(\mathrm{p}<0.05)$. However no significant differences were observed in serum high sensitivity Creactive protein $(\mathrm{p}=0.288)$ and heat shock protein 70 $(p=0.960)$ levels between metabolic syndrome and obese subjects. There was a significant positive correlation between serum S100A12, matrix Gla protein and heat shock protein 70 levels in both groups.

Conclusions: Our findings showed a significant association between heat shock protein 70, S100A12, matrix Gla protein, and obesity and metabolic syndrome. Obesity may be involved in increased risk of developing metabolic syndrome. It might be useful to focus on the roles of these proteins in obesity in accordance with the prevention of the development of metabolic syndrome and other metabolic disorders like diabetes.

Key Words: Obesity, metabolic syndrome, heat shock protein $70, \mathrm{~S} 100 \mathrm{~A} 12$ and matrix Gla protein

\section{ÖZET}

Amaç: Metabolik Sendromun primer nedeni erişkin ve çocuk popülasyonunda insülin rezistansı ile sonuçlanan düşük dereceli inflamasyon ile ilgili obezitedir. Heat şok protein 70, S100A12 ve matriks Gla protein kronik inflamatuar hastalık ile ilgilidir. Çocuk çă̆ı obezitesi ve metabolik sendromun da bu markırları değerlendirmeyi amaçladık.

Gereç ve Yöntem: Bu çalışma 10-15 yaş aralığında 45 obez çocuk ve 47 metabolik sendrom'lu çocukta yapıldı. Heat şok protein 70, S100A12 ve matriks Gla protein ELISA metodu kullanılarak ölçüldü.

Bulgular: Obez çocuklarda serum matriks Gla protein ve S100A12 seviyeleri metabolik sendrom'lu gruptan anlamli olarak yüksekti $(\mathrm{p}<0.05)$. İlaveten, metabolik sendrom ve obez bireyler arasinda serum hsCRP $(\mathrm{p}=0.288)$ ve heat şok protein $70(p=0.960)$ fark yoktu. Her iki grupta S100A12, matriks Gla protein ve heat şok protein 70 seviyeleri arasında anlamlı pozitif korelasyon vardı.

Sonuç: Bulgularımız S100A12, matriks Gla protein ve heat şok protein 70 biyomarkırları metabolik sendrom ve obezite ile anlamlı olarak ilgili olduğunu gösterdi. Obezite metabolik sendrom gelişiminde önemli bir risk faktörüdür. Obezitede bu proteinlerin artışı, metabolik sendrom ve diabet gibi metabolik bozuklukların gelişiminin önlenmesinde ilgi çekici olabilir.

Anahtar Kelimeler: Obezite, metabolik sendrom, heat şok protein 70, S100A12, matriks Gla protein 


\section{Introduction}

The rise in the prevalence of obesity in children and adolescents, which has reached pandemic proportions, is associated with increased morbidity and mortality $(1,2)$. Childhood obesity is a chronic, low-grade pro-inflammatory state and is associated with components of metabolic syndrome (MS) such as insulin resistance (IR), abnormal glucose metabolism, elevated blood pressure and dyslipidemia (2,3). S100A12 (calgranulin C), a low molecular weight (9-14 $\mathrm{kDa}$, calcium-binding, proinflammatory and cytosolic protein, and is found in human neutrophils and monocytes macrophages (4). S100A12 are involved in chronic inflammatory diseases (4). Heat shock protein 70 (Hsp70) is molecular chaperones that binds to protein substrates and facilitate protein transport, regulation and folding under physiological conditions $(5,6)$. Hsp70 binds to surface receptors on immune and epithelial cells and trigger an immune-inflammatory response (5). Matrix Gla $[\gamma-$ carboxyglutamic acid] protein (MGP) is an extracellular vitamin $\mathrm{K}$-dependent matrix protein and a potent inhibitor of vascular calcification (7). MGP is related to extracellular matrix binding and apoptosis, as well as tissue growth and development (8). The etiology of obesity and MS is not completely understood in children and adolescents. In our knowledge, there were no studies serum levels of S100A12, MGP and HSP70 in childhood obesity and MS. However, little is known about their dysregulation during the course of obesity, particularly in MS subjects in the literature. The primary aim of this study was to determine the association between S100A12, MGP and HSP70 levels, and childhood obesity and MS.

\section{Material and Methods}

Study population: This study was performed in 45 obese children aged 10-15 yr (mean 13.03 \pm 1.63 yr) and 47 children with MS aged 10-15 yr (mean $13.62 \pm 1.42 \mathrm{yr}$ ). The children diagnosed with MS and obesity in the outpatient clinic of the pediatric endocrinology department were recruited for this study. The Ethics Committee approved the study protocol. All subjects were informed about the details of the study. The written consent of each patient was obtained. Exclusion criteria were diabetes mellitus (DM), chronic disease, a history of cardiovascular disease (CVD), genetic disorders, smoking and taking supplementary vitamins. Obesity was defined as body mass index $(B M I) \geq 95$ th percentile for age and sex according to BMI reference curves for Turkish children $(9,10)$. Pubertal stage was determined in both obese and MS groups according to the Tanner criteria and validated by plasma sex hormone concentrations (11). MS in children was defined by using the International Diabetes Federation criteria (waist circumference (WC) >90th percentile with any two of the parameters triglyceride (TG) $\geq 150 \mathrm{mg} / \mathrm{dL}$, high density lipoprotein cholesterol (HDL) $<40 \mathrm{mg} / \mathrm{dL}$, fasting plasma glucose (FPG) $>100 \mathrm{mg} / \mathrm{dL}$ and blood pressure (BP) $>130 / 85 \mathrm{mmHg}$ ) (12).

\section{Anthropometric measurements: All} anthropometric measurements were made with participants wearing light clothing and no shoes. BMI was measured in all participants and calculated as weight (in kilograms) divided by height (in meters) squared. WC were measured with a soft tape midway between the lowest rib and the iliac crest.

Biochemical analysis: Blood samples $(5 \mathrm{ml})$ were obtained after an overnight fasting in empty vacuum tubes. Serum samples were obtained after centrifugation and stored frozen at $-80{ }^{\circ} \mathrm{C}$ until the day of analysis. Serum biochemical analyte levels were measured immediately. The homeostasis model assessment of insulin resistance (HOMA-IR) was calculated as fasting serum insulin $(\mu \mathrm{U} / \mathrm{ml}) \times$ FPG $(\mathrm{mmol} / \mathrm{l}) / 22.5$ and used as an index of insulin resistance. HOMA-IR scores $\geq 2.5$ shows insulin resistance (7). An oral glucose tolerance test was performed $(1.75 \mathrm{~g}$ of glucose/1 kg; glucose/insulin measured at baseline, $1^{\text {st }} \mathrm{h}$ and $2^{\text {nd }} \mathrm{h}$ ) in obese subjects.

Analyses of other analytes: Serum biochemical analyte levels were measured by commercially available kits based on routine methods on the Architect C 8000 System (Abbott Laboratories, Abbott Park, Illinois, USA). Serum insulin was determined by routine chemiluminescence method on E170 analyzer (Roche Diagnostics, Mannheim Germany). High sensitivity C-reactive protein (hsCRP) was measured by a highly sensitive immunonefelometric assay using Cardio-Phase hsCRP on BN II Dade Behring analyzer (Dade Behring Marburg GmBH; Marburg, Germany). The analyses of serum S100A12, MGP and Hsp70 levels were performed using an enzyme immunoassay method using commercial kits (MybioSource Human Elisa Kits, MyBioSource, Inc. San Diego, USA) in accordance with the manufacturer's guidelines. Absorbance was measured at $450 \mathrm{~nm}$ on an ELx800 Absorbance 
Table 1. Demographic and biochemical data of obese and MS children

\begin{tabular}{|c|c|c|c|}
\hline & $\begin{array}{c}\text { MS Subjects } \\
\mathrm{n}=47\end{array}$ & $\begin{array}{c}\text { Obese Subjects } \\
n=45\end{array}$ & $\mathrm{p}$ Value \\
\hline Age (years) & $13.62 \pm 1.42$ & $13.03 \pm 1.63$ & 0.94 \\
\hline Gender (Male/Female) & 22M. $25 \mathrm{~F}$ & 21M. 24F & 0.989 \\
\hline BMI $\left(\mathrm{kg} / \mathrm{m}^{2}\right)$ & $32.82 \pm 5.23$ & $31.64 \pm 4.69$ & 0.304 \\
\hline Weight (kg) & $84.87 \pm 18.22$ & $79.52 \pm 16.08$ & 0.181 \\
\hline Height $(\mathrm{cm})$ & $160.20 \pm 8.58$ & $158.22 \pm 9.47$ & 0.340 \\
\hline Waist circumferance $(\mathrm{cm})$ & $101.71 \pm 10.83$ & $100.17 \pm 11.97$ & 0.554 \\
\hline Age SDs & $2.71 \pm 0.96$ & $2.66 \pm 0.99$ & 0.834 \\
\hline Height SDs & $0.09 \pm 1.11$ & $0.43 \pm 1.52$ & 0.190 \\
\hline BMI p & $99.04 \pm 1.45$ & $98.91 \pm 1.53$ & 0.714 \\
\hline BMI SDs & $2.75 \pm 0.68$ & $2.66 \pm 0.69$ & 0.605 \\
\hline Systolic BP (mmHg) & $123.57 \pm 21.81$ & $115.12 \pm 16.29$ & 0.063 \\
\hline Diastolic BP $(\mathrm{mmHg})$ & $75.14 \pm 14.06$ & $71.31 \pm 9.69$ & 0.178 \\
\hline Fasting glucose $(\mathrm{mg} / \mathrm{dL})$ & $88.46 \pm 12.75$ & $83.70 \pm 8.59$ & 0.066 \\
\hline Fasting insulin $(\mu \mathrm{IU} / \mathrm{mL})$ & $26.04 \pm 16.33$ & $18.91 \pm 9.75$ & $<0.05$ \\
\hline $2^{\text {nd }} \mathrm{h}$ glucose $(\mathrm{mg} / \mathrm{dL})$ & $124.29 \pm 36.61$ & $106.79 \pm 20.37$ & $<0.05$ \\
\hline $2^{\text {nd }} \mathrm{h}$ insulin $(\mu \mathrm{IU} / \mathrm{mL})$ & $143.27 \pm 128.49$ & $113.32 \pm 87.43$ & 0.246 \\
\hline HOMA-IR & $5.93 \pm 3.61$ & $3.97 \pm 2.00$ & $<0.01$ \\
\hline Puberty & $4.09 \pm 1.22$ & $4.05 \pm 1.29$ & 0.888 \\
\hline Triglycerides $(\mathrm{mg} / \mathrm{dL})$ & $188.63 \pm 78.85$ & $110.24 \pm 41.84$ & $<0.001$ \\
\hline Total C $(\mathrm{mg} / \mathrm{dL})$ & $176.97 \pm 36.58$ & $177.02 \pm 31.38$ & 0.995 \\
\hline HDL-C (mg/dL) & $36.5 \pm 6.93$ & $43.19 \pm 7.47$ & $<0.001$ \\
\hline LDL-C (mg/dL) & $101.92 \pm 32.66$ & $111.52 \pm 27.12$ & 0.174 \\
\hline $\operatorname{ALT}(\mathrm{U} / \mathrm{L})$ & $36.88 \pm 29.81$ & $22.74 \pm 13.40$ & $<0.05$ \\
\hline $\operatorname{AST}(\mathrm{U} / \mathrm{L})$ & $33.52 \pm 18.71$ & $22.50 \pm 9.88$ & $<0.05$ \\
\hline
\end{tabular}

All values are mean \pm standard deviation.

MS:Metabolic syndrome, BMI: Body mass index, BP: Blood pressure, Total C: Total cholesterol. HDL-C:High density lipoprotein-cholesterol, HOMA-IR: Homeostasis model assessment of insulin resistance, LDL-C: Low density lipoprotein-cholesterol, SDs: Standard deviation score, ALT: Alanine aminotransferase, AST: Aspartate aminotransferase.

Microplate Reader (Biotek, Winooski, VT, USA). Concentration values were reported in $\mathrm{ng} / \mathrm{ml}$ for S100A12 and Hsp70, and in $\mathrm{pg} / \mathrm{ml}$ for MGP.

Statistical analysis: All data are expressed as mean \pm standard deviations (SD). Statistical analyses were done using SPSS v. 16.0 (SPSS Inc., IL, USA). To compare the ratio of categorical variables, we used the chi-squared test [gender (Male/Female)]. The normality of the variables was evaluated using the one-sample KolmogorovSmirnov test. The independent samples $t$ tests were used for comparing mean and median values. The correlations between variables were performed by Pearson's Correlation test. Differences were considered significant at a probability level of $\mathrm{p}<0.05$.

\section{Results}

Demographic and biochemical data of obese and MS children were presented in Table 1. As seen, age, puberty and gender distributions between MS and obese groups were similar. Serum fasting insulin $(\mathrm{p}<0.05), 2^{\text {nd }} \mathrm{h}$ glucose $(\mathrm{p}<0.05)$, alanine aminotransferase (ALT) $\quad(\mathrm{p}<0.05)$ and aspartate aminotransferase (AST) $(\mathrm{p}<0.05)$, TG $(\mathrm{p}<0.001)$ levels and HOMA-IR $(\mathrm{p}<0.01)$ in MS groups were significantly higher than obese groups. Whereas serum HDL-C levels in the MS groups were lower, compared with those of the obese groups $(p<0.001)$. Serum MGP and S100A12 levels in the MS groups were lower than those of the obese groups were $(\mathrm{p}<0.05)$. In addition, no significant 
differences were observed in serum hsCRP ( $\mathrm{p}=$ 0.288) and Hsp70 ( $p=0.960)$ levels between MS and obese subjects (Table 2). Simple correlation analyses were performed to investigate the association between serum Hsp70,MGP, and S100A12 levels. The levels of S100A12 were positively correlated with MGP $(\mathrm{p}<0.001$; $\mathrm{r}=0.761)$ and Hsp70 $(\mathrm{p}<0.05 ; \mathrm{r}=0.373)$, and the levels of MGP were positively correlated with Hsp70 ( $<<0.001 ; \mathrm{r}=0.573)$ and AST $(\mathrm{p}<0.05 ; \mathrm{r}$ $=0.422$ ) in obese groups. In the MS group, the levels of S100A12 were positively correlated with MGP ( $\mathrm{p}<0.001 ; \mathrm{r}=0.892)$ and Hsp70 $(\mathrm{p}<0.05 ; \mathrm{r}$ $=0.353)$, and the levels of MGP were positively correlated with TG $(p<0.05 ; \mathrm{r}=0.339)$ and Hsp70 $(\mathrm{p}<0.05 ; \mathrm{r}=0.403)$. HOMA-IR was positively correlated with serum Hsp70 ( $<<0.05 ; r=0.421$ ).

\section{Discussion}

In this study, we compared the serum Hsp70, S100A12, MGP and hsCRP levels in obese and MS children. In our knowledge, these markers have not been studied in obese and MS children together, so far. We found no significant difference in serum Hsp70 and hsCRP levels between MS and obese subjects. However, serum MGP and S100A12 levels in the MS group were lower than those of the obese group were. There were a significant positive correlation between serum S100A12, MGP and Hsp70 levels in both groups.

The primary cause of the MS appears to be obesity leading to hyperglycemia through defects in insulin action in both adult and pediatric populations (3). This process may be mediated by abnormal levels of inflammatory markers such as adipokines and cytokines associated with visceral obesity (3). S100A12 binds to the receptor for advanced glycation end products (RAGE) in endothelium and monocyte/macrophages leading to production of proinflammatory cytokines and induces the expression of adhesion molecules attracting inflammatory cells (4). S100A12 may increase expression of osteoblastic genes and facilitate calcification (13). Hyperglycemia might stimulate S100A12 protein production, either directly in granulocytes and monocytes or indirectly via hyperglycemia-produced cytokines (14). Kosak1 et al. (15) observed that the mean of plasma S100A12 levels was twice as high in the DM group, compared with the non-DM group. Mortensen et al. (16) demonstrated that plasma calprotectin (S100A8 and S100A9) was increased in obese relative to non-obese controls and was slightly increased in obese relative to obese patients with T2DM, but did not differ between obese and obese patients with T2DM groups. Ryder et al. (17) found that the obese subjects with normal levels of insulin had elevated levels of serum and cell inflammatory markers compared to the obese group with IR. The subjects with IR had high levels of serum insulin but there were not inflammatory consequences. The leukocytes showed increased number of cells S100A12 protein in obese subjects without IR. Insulin can induce IR by impairment signaling of insulin receptor. Our results were in concordance with this study. We found serum S100A12 levels were decreased in the MS groups relative to obese groups.

In stress conditions, including metabolic stress, inflammation, oxidative stress, and endothelial injury, Hsp70 can released into the circulation (6). There was a significant increase in the expression of Hsp70 in the subcutaneous adipose tissue and peripheral blood mononuclear cells of obese group compared to lean group (6). Increase those proteins in nondiabetic obese sustain to prevent the development of further metabolic disorders including MS and diabetes. Reduced expression of intracellular HSP was also linked to MS complicated by obesity (6). In obesity, dysregulation of Hsp 70 contribute to the pathogenesis and/or progression of IR which

Table 2. Serum biomarkers of obese and MS children

\begin{tabular}{lccc}
\hline & $\begin{array}{c}\text { MS Subjects } \\
\mathrm{n}=47\end{array}$ & $\begin{array}{c}\text { Obese Subjects } \\
\mathrm{n}=45\end{array}$ & p Value \\
\hline MGP $(\mathrm{pg} / \mathrm{mL})$ & $114.50 \pm 85.37$ & $174.80 \pm 131.76$ & $<0.05$ \\
\hline S100A12 $(\mathrm{ng} / \mathrm{mL})$ & $2.53 \pm 2.22$ & $3.77 \pm 2.70$ & $<0.05$ \\
\hline $\mathrm{h} s \mathrm{CPP}(\mathrm{mg} / \mathrm{L})$ & $4.51 \pm 5.58$ & $3.25 \pm 2.90$ & 0.288 \\
\hline Hsp70 $(\mathrm{ng} / \mathrm{mL})$ & $21.22 \pm 17.03$ & $21.03 \pm 15.92$ & 0.960 \\
\hline
\end{tabular}

All values are mean \pm standard deviation.

hsCRP: High sensitive C-reactive protein, Hsp70: Heat shock protein 70, MGP: Matrix Gla protein 
leads to a reduced ability to express Hsp70 and causes cell damage (18). There were no significant difference in Hsp70 and anti-Hsp70 between women with MS and the control group (5). Armutcu et al. (19) observed a decrease in Hsp70 levels in MS patients. Contrarily to existing literature, we found that there were no significant difference in serum Hsp70 levels between MS and obese children. MGP is found in blood cells such as neutrophils, lymphocytes, and plasmocytes (20). The MGP is known to play a role in human pathologies in inflammatory processes and leads to ectopic calcifications (20). In a study, MGP has been demonstrated in MGP-deficient animals, which all died of massive arterial calcification within 6-8 weeks after birth (20). MGP binds to fibronectin, vitronectin, and fibrinogen and enhances cell attachment to fibronectin (21). Hsp70 was identified as a novel MGP-binding protein and enhances BMP induced calcium deposition, thereby functioning as a potential link between cellular stress and inflammation (22). In a study, it has been shown that Hsp70 increased the effect of BMP-4 on endothelial cells and mediated a procalcific effect of interleukin-6 (IL-6) (22). In our study, serum MGP levels in the MS group were lower than those of the obese group. We think that IR in MS leads to reduce serum S100A12, HSP70 and MGP levels in children.

In conclusion, these results suggest that serum S100A12, HSP70 and MGP levels are regulated by factors related to subclinical inflammation with MS and obesity of childhood. Based on these evidences, it was suggested that increasing S100A12, HSP70 and MGP could be considered a therapeutic strategy to protect from insulin resistance, and delay or avoid clinical complications such as MS in obesity. Further studies with increased sample size are required to determine causal relationships between obesity and MS to elucidate underlying mechanisms.

Author disclosure: The authors stated that there are no conflicts of interest regarding the publication of this article.

Conflicts of interest statement: This study was financially supported by Konya Education and Research Hospital. No financial or other potential conflicts of interest exist.

\section{References}

1. Morandi A, Maffeis C. Predictors of metabolic risk in childhood obesity. Horm Res Paediatr 2014; 82(1): 3-11.
2. Weiss R, Bremer AA, Lustig RH. What is metabolic syndrome, and why are children getting it? Ann N Y Acad Sci 2013; 1281: 123-140.

3. Lee L, Sanders RA. Metabolic syndrome. Pediatr Rev 2012; 33(10): 459-466.

4. Day AS, Ehn M, Gearry RB, Lemberg DA, Leach ST. Fecal S100A12 in healthy infants and children. Dis Markers 2013; 35(5): 295-299.

5. Nahas EA, Nahas-Neto J, Orsatti CL, Tardivo AP, Uemura G, Peraçoli MT et al. The 60- and $70-\mathrm{kDa}$ heat-shock proteins and their correlation with cardiovascular risk factors in postmenopausal women with metabolic syndrome. Cell Stress Chaperones 2014; 19(4): 559-568.

6. Tiss A, Khadir A, Abubaker J, Abu-Farha M, AlKhairi I, Cherian P, et al. Immunohistochemical profiling of the heat shock response in obese non-diabetic subjects revealed impaired expression of heat shock proteins in the adipose tissue. Lipids Health Dis 2014; 13: 106.

7. Shroff R, Dégi A, Kerti A, Kis E, Cseprekál O, Tory $\mathrm{K}$, et al. Cardiovascular risk assessment in children with chronic kidney disease. Pediatr Nephrol. 2013; 28(6): 875-884.

8. Dalmeijer GW, van der Schouw YT, Magdeleyns EJ, Vermeer C, Verschuren WM, Boer JM, et al. Matrix Gla protein species and risk of cardiovascular events in type 2 diabetic patients. Diabetes Care 2013; 36(11): 3766-3771.

9. Neyzi O, Furman A, Bundak R, Gunoz H, Darendeliler F, Bas F. Growth references for Turkish children aged 6 to 18 years. Acta Paediatr 2006; 95(12): 1635-1641.

10. Bundak R, Furman A, Gunoz H, Darendeliler F, Bas F, Neyzi O. Body mass index references for Turkish children. Acta Paediatr 2006; 95(2): 194198.

11. Marshall WA, Tanner JM. Variations in the pattern of pubertal changes in boys. Arch Dis Child 1970; 45(239): 13-23.

12. Zimmet P, Alberti KG, Kaufman F, Tajima N, Silink M, Arslanian S, et al. The metabolic syndrome in children and adolescents - an IDF consensus report. Pediatr Diabetes 2007; 8(5): 299-306.

13. Hofmann Bowman M, Wilk J, Heydemann A, Kim G, Rehman J, et al. S100A12 mediates aortic wall remodeling and aortic aneurysm. Circ Res 2010; 106(1): 145-154.

14. Hasegawa T, Kosaki A, Kimura T, Matsubara H, Mori Y, Okigaki M, et al. The regulation of ENRAGE (S100A12) gene expression in human THP-1 macrophages. Atherosclerosis 2003; 171(2): 211-218.

15. Kosaki A, Hasegawa T, Kimura T, Iida K, Hitomi J, Matsubara H, et al. Increased plasma S100A12 (ENRAGE) levels in patients with type 2 diabetes. J Clin Endocrinol Metab 2004; 89(11): 5423-5428. 
16. Mortensen $\mathrm{OH}$, Nielsen AR, Erikstrup C, Plomgaard P, Fischer CP, Krogh-Madsen R, et al. Calprotectin-a novel marker of obesity. PLoS One 2009; 4(10): e7419.

17. Ryder E, Pedreañez A, Vargas R, Peña C, Fernandez E, Diez-Ewald $M$, et al.. Increased proinflammatory markers and lipoperoxidation in obese individuals: Inicial inflammatory events? Diabetes Metab Syndr 2015; 9(4): 280-286.

18. Simar D, Jacques A, Caillaud C. Heat shock proteins induction reduces stress kinases activation, potentially improving insulin signalling in monocytes from obese subjects. Cell Stress Chaperones 2012; 17(5): 615-621.

19. Armutcu F, Ataymen M, Atmaca H, Gurel A. Oxidative stress markers, C-reactive protein and heat shock protein 70 levels in subjects with metabolic syndrome. Clin Chem LabMed 2008; 46(6): 785-790.

20. Luo G, Ducy P, McKee MD, Pinero GJ, Loyer E, Behringer RR, et al. Spontaneous calcification of arteries and cartilage in mice lacking matrix GLA protein. Nature 1997; 386: 78-81.

21. Nishimoto SK, Nishimoto M. Matrix gla protein binds to fibronectin and enhances cell attachment and spreading on fibronectin. Int $\mathrm{J}$ Cell Biol 2014; 2014: 807013.

22. Yao Y, Watson AD, Ji S, Boström KI. Heat shock protein 70 enhances vascular bone morphogenetic protein-4 signaling by binding matrix Gla protein. Circ Res 2009; 105(6): 575584. 